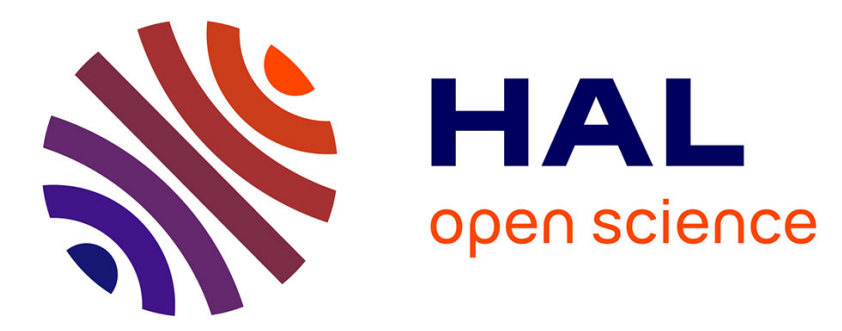

\title{
Joined by geochemistry, divided by history: PCBs and PBDEs in Strait of Georgia sediments
}

S.C. Johannessen, R.W. Macdonald, C.A. Wright, B. Burd, D.P. Shaw, A. van Roodselaar

\section{- To cite this version:}

S.C. Johannessen, R.W. Macdonald, C.A. Wright, B. Burd, D.P. Shaw, et al.. Joined by geochemistry, divided by history: PCBs and PBDEs in Strait of Georgia sediments. Marine Environmental Research, 2008, 66, 10.1016/j.marenvres.2008.03.003 . hal-00563032

\section{HAL Id: hal-00563032 \\ https://hal.science/hal-00563032}

Submitted on 4 Feb 2011

HAL is a multi-disciplinary open access archive for the deposit and dissemination of scientific research documents, whether they are published or not. The documents may come from teaching and research institutions in France or abroad, or from public or private research centers.
L'archive ouverte pluridisciplinaire HAL, est destinée au dépôt et à la diffusion de documents scientifiques de niveau recherche, publiés ou non, émanant des établissements d'enseignement et de recherche français ou étrangers, des laboratoires publics ou privés. 


\section{Accepted Manuscript}

Joined by geochemistry, divided by history: PCBs and PBDEs in Strait of Geor gia sediments

S.C. Johannessen, R.W. Macdonald, C.A. Wright, B. Burd, D.P. Shaw, A. van Roodselaar

PII:

S0141-1136(08)00118-9

DOI: 10.1016/j.marenvres.2008.03.003

Reference: MERE 3246

To appear in:

Marine Environmental Research

Received Date:

2 November 2007

Revised Date: 25 February 2008

Accepted Date: 25 March 2008

Please cite this article as: Johannessen, S.C., Macdonald, R.W., Wright, C.A., Burd, B., Shaw, D.P., van Roodselaar, A., Joined by geochemistry, divided by history: PCBs and PBDEs in Strait of Georgia sediments, Marine Environmental Research (2008), doi: 10.1016/j.marenvres.2008.03.003

This is a PDF file of an unedited manuscript that has been accepted for publication. As a service to our customers we are providing this early version of the manuscript. The manuscript will undergo copyediting, typesetting, and review of the resulting proof before it is published in its final form. Please note that during the production process errors may be discovered which could affect the content, and all legal disclaimers that apply to the journal pertain. 
Joined by geochemistry, divided by history: PCBs and PBDEs in Strait of Georgia sediments

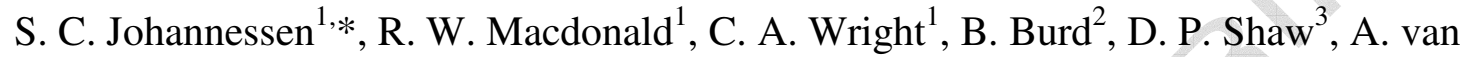
Roodselaar $^{4}$

${ }^{1}$ Fisheries and Oceans Canada, Institute of Ocean Sciences, 9860 W. Saanich Rd., P.O. Box 6000, Sidney, B.C., Canada, V8L 4B2

${ }^{2}$ Ecostat Research Ltd., 1040 Clayton Rd., N. Saanich, B.C., Canada, V8L 5P6

${ }^{3}$ Environment Canada, \#201-401 Burrard St., Vancouver, B.C., Canada, V6C 3S5

${ }^{4}$ Metro Vancouver, 4330 Kingsway, Burnaby, B.C., Canada, V5H 4G8

* Corresponding author: tel. (250) 363-6616, fax (250) 363-6310, johannessen@ pac.dfompo.gc.ca

\section{Abstract}


2 Polychlorinated biphenyls (PCBs) are relict contaminants, while polybrominated

3 diphenyl ethers (PBDEs) are in increasing use. Using sediment cores collected in the

4 Strait of Georgia, we demonstrate that the surface sediment concentration of PCBs is

5 largely determined by environmental processes, such as sediment accumulation and

6 mixing rates, while that of PBDEs is strongly influenced by proximity to source. The

7 Iona Island wastewater outfall appears to be a primary pathway for PBDEs. As well,

8 Vancouver Harbour is highly contaminated with both classes of chemical. BDE-209, the

9 main component of deca-BDE, is the dominant PBDE congener. Environmental

10 debromination is not evident. Currently, the ranges of the surface concentration of PCBs

11 and PBDEs are similar to one another, but that will change in the future, as the

12 concentration of PBDEs continues to rise. The experience with PCBs suggests that if

13 PBDEs were banned today, it would take decades for inorganic sediment to bury them.

17 PCB, PBDE, contamination history, sediment, cores, Strait of Georgia 


\section{1. Introduction}

19 Polychlorinated biphenyls (PCBs) and polybrominated diphenyl ethers (PBDEs) are

20 persistent, toxic, bioaccumulative, manufactured chemicals that are widely distributed in

21 the environment, but their histories of use are different (Alaee, 2006; De Wit, 2002;

22 Rapaport and Eisenreich, 1988). Introduced in the 1930s as lubricants and liquid

23 insulators and later used for a wide variety of industrial and household uses, PCBs

24 (estimated total global usage of 1.2 Mt, Macdonald et al., 2000) were banned in stages in

25 the late 1970 s and early 1980 s as a result of concerns over their effects on the

26 environment and on human health (Fig. 1). Despite their having been banned about 30

27 years ago, PCBs continue to cycle in marine and terrestrial ecosystems, where they still

28 present health threats, especially to high trophic level, long-lived animals like killer

29 whales (Hickie et al., 2007; Ross et al., 2000).

31 PBDEs are more recent arrivals, used primarily as flame retardants on household goods,

32 including furniture and electronics. Their production was estimated at $40 \mathrm{kt} / \mathrm{yr}$ in 1990

33 and had grown to about $70 \mathrm{kt} / \mathrm{yr}$ by the late 1990s (Wania and Dugani, 2003). PBDEs

34 appeared in the marine environment in the late 1970s and have been increasing in

35 concentration ever since. They have been measured in sediment, water, and marine

36 organisms (for example de Boer et al., 1998; Elliott et al., 2005; Ikonomou et al., 2006;

37 Ross, 2006), where they pose a threat as disrupters of the thyroid hormone system, which

38 controls the development of the central nervous system (Martin et al., 2004). PBDEs

39 have been used in three market formulations: penta, octa and deca. The penta

40 formulation, which contains the lightest congeners, was voluntarily phased out of use in 
41 Canada in the early 2000s, and has recently been banned in Canada, the United States and

42 parts of Europe. The octa formulation has not been used locally. However, the heaviest

43 industrial formulation, deca-BDE, remains on the market. PCBs and PBDEs are particle-

44 reactive, especially the heavier PBDE congeners (de Boer et al., 2003), so marine

45 sediments serve as an archive of the fate of these chemicals and as a proxy for their

46 historical discharge to the marine environment.

48 The Strait of Georgia (Fig. 2), a large inland sea on the west coast of British Columbia,

49 Canada, has a rapidly growing population of $\sim 4$ million, almost half of whom live in

50 Greater Vancouver, at the mouth of the Fraser River. The Strait has long been valued for

51 fishing, transportation and recreation, but, like most coastal seas, it has also been used

52 directly and indirectly for discharge of industrial waste, including pulp mill, mining and

53 municipal wastewater effluents. Sediments in the Strait of Georgia record the entry of a

54 wide variety of anthropogenic contaminants, including lead (Macdonald et al., 1991),

55 mercury (Johannessen et al., 2005), chlorinated dioxins and furans (PCDD/Fs) and PCB-

5677 (Macdonald et al., 1992), polynuclear aromatic hydrocarbons (PAHs, Yunker and

57 Macdonald, 2003) and industrial detergents (Shang et al., 1999).

59 Here we examine dated sediment cores collected from the Strait of Georgia which have

60 been analyzed for PCB and PBDE congeners. We use these sedimentary records in

61 comparison with other records, including sediment traps and effluent analyses, to infer

62 the controls on the distributions of PCBs and PBDEs in the sediments, to seek evidence

63 for debromination of deca-BDE to lighter, more toxic congeners, and to assess the present 
64 role of the Iona Island wastewater outfall, which discharges directly into the Strait, in the

65 delivery of these chemicals to the Strait of Georgia.

\section{2. Methods}

$68 \quad 2.1$ Sediment core collection and dating

69 Seven sediment cores were collected in 2003 and 2004 from the central and northern

70 Strait of Georgia (Fig. 2), using a Pouliot box corer $(20 \mathrm{~cm} \times 30 \mathrm{~cm}$ cross section). The

71 cores were all approximately $50 \mathrm{~cm}$ long and composed mainly of silty mud.

72 Immediately on recovery, the cores were sectioned for analysis into $1 \mathrm{~cm}$ intervals for the

73 top $10 \mathrm{~cm}, 2 \mathrm{~cm}$ intervals for the next $10 \mathrm{~cm}$ and $5 \mathrm{~cm}$ intervals for the remainder of the

74 core. A subsample from each depth interval was analyzed by Flett Research Ltd.,

75 Winnipeg, Canada, for ${ }^{210} \mathrm{~Pb}$ and ${ }^{226} \mathrm{Ra}$ to be used for radio-dating. ${ }^{210} \mathrm{~Pb}$ was measured

76 in all sections of each core ( 22 samples / core), following the procedure of Eakins and

77 Morrison (1978), in which the activity of ${ }^{210} \mathrm{~Pb}$ is inferred from that of ${ }^{210} \mathrm{Po}$ (counting

78 errors $<3 \%$ ). The activity of supported ${ }^{210} \mathrm{~Pb}$ was determined as the average of the ${ }^{226} \mathrm{Ra}$

79 activity measured at three depths (top, middle, bottom) in each core, from the ingrowth of

$80 \quad{ }^{222} \mathrm{Rn}$ over at least 4 days.

81

82 Since the bottom waters of the Strait of Georgia are oxygenated, there is an active benthic

83 community, and the surface sediments are bioturbated. The depth of the surface mixed

84 layer in each core was determined by eye as the inflection point in the depth profile of the 85 natural $\log$ of ${ }^{210} \mathrm{~Pb}$ (Fig. 3). The sedimentation and mixing rates were determined 
86 assuming a constant supply of ${ }^{210} \mathrm{~Pb}$ and a constant sedimentation rate (Robbins, 1978),

87 with mixing described by advective-diffusive equations (Lavelle et al., 1986).

\section{$89 \quad 2.2$ Sediment traps}

90 Moorings with two sediment traps each (attached 20 and $50 \mathrm{~m}$ off the bottom) were set

91 out at stations GVRD-A1 and GVRD-B1 (Fig. 2) in October 2003 and retrieved in April

92 2004. Each trap collected 10 sequential samples that represented 21 days each. For each

93 trap, we took a subsample from each of the 10 sequential vials, homogenized the

94 subsamples and sent them for analysis of PCBs and PBDES, as described in section 2.4.

95 The data from the traps were used for comparison of the congener patterns with those

96 measured in the sediment cores.

\section{$98 \quad 2.3$ Carbon and nitrogen analysis}

99 Carbon and nitrogen were analysed in the sediment core samples at the University of

100 British Columbia, using the method of Calvert et al. (1995), in which the concentration of

101 organic carbon is calculated as the difference between the concentrations of total and

102 carbonate carbon. Total carbon is measured by combustion and gas chromatography in a

103 CHS analyzer and carbonate carbon by coulometry (precision $\pm 1.6 \%, 1$ standard

104 deviation).

2.4 Analysis of PCBs and PBDEs

107 A full suite of 209 PCB congeners, with some co-elutions, and 40 PBDE congeners were

108 measured by AXYS Analytical Services Ltd, in Sidney, B.C.. Both the PCBs and the 
109 PBDEs were measured by high resolution gas chromatography / high resolution mass

110 spectroscopy (general precision $\pm 30 \%$; precision of duplicates in a batch $\pm 20 \%$ of the

111 mean). The PCB analysis was conducted according to the United States Environmental

112 Protection Agency method EPA 1668A (EPA, 2003a), the PBDE analysis, according to 113 method EPA 1614 (EPA, 2003b).

1152.5 Calculation of 10-year inventories of PCBs and PBDEs in sediment cores

116 We calculated inventories of PCBs and PBDEs in the sediment cores for comparison with

117 the surface concentration values. Unfortunately, the sedimentation rates at four of the

118 stations (GVRD-3, -4, -5 and -6) were so high that the 50-cm core records were not long

119 enough to capture the entire PCB record, which commenced in $~ 1930$. Accordingly, we

120 could not calculate a complete inventory for every core and have, instead, compared the

121 inventories over a shorter period. Benthic mixing makes it inappropriate to assign a

122 discrete date to any particular depth in these cores (See Guinasso and Schink, 1975 for

123 explanation of the age-smearing effect of benthic mixing). We estimated a 10-year

124 inventory for each core using a core depth that was scaled according to the sedimentation

125 rate (sedimentation velocity at each site $(\mathrm{cm} / \mathrm{yr})$ multiplied by 10 years). In general, this

126 method overestimates the inventory of the last 10 years of PCB deposition, since the

127 concentration of that contaminant is decreasing, and the benthic organisms mix older,

128 more highly contaminated material into the surface layer. Conversely, it underestimates

129 the PBDE inventory because of the mixing of older, cleaner sediment into the surface

130 layer. However, it provides a reasonable basis for comparison among the cores, since the 131 biases are in the same direction for all cores. 


\section{2.6 Modelling historical deposition of PCBs and PBDEs}

134 Bioturbation of surface sediment modifies the profile shape of a transient contaminant as

135 it passes through this mixed layer (e.g. Guinasso and Schink, 1975). We therefore

136 modelled the historical deposition of PCBs in the cores, using a program developed in

137 Matlab $^{\mathrm{TM}}$ (Johannessen et al., 2005) that explicitly accounts for the sedimentation and

138 mixing rates. The method is most robust where there is an abrupt change, however, and

139 there are too many degrees of freedom in the model to describe uniquely a flux that varies

140 gradually, as those of both PCBs and PBDEs have done in most of these cores. However,

141 at station GVRD-3, there was an abrupt change in the PCB concentration flux (as

142 discussed in Section 3), and the model illustrates the effect of the newly-constructed

143 outfall on the concentration of PCBs in the incident surface sediment. We have also used

144 the model fit to some profiles (in Section 3) for a graphic illustration of the main trends

145 with time.

148 3. Results and discussion

149 The concentration profiles in the sediments clearly reflect the known histories of PCB

150 and PBDE discharge (Figs. 4 and 5). PCBs appeared in 1930, increased rapidly until

151 the late 1960s, and then decreased. PBDEs first entered the local sediments in 1978 and

152 have been increasing rapidly ever since. Because of the relatively high sedimentation

153 rates at stations GVRD-3, $-4,-5$ and -6 , the deepest levels in those cores do not predate

154 the entry of PCB into the environment (1930), but the recent PCB decline is reflected in 
155 every core. (The sedimentation rate at station GVRD-4, near the mouth of the Fraser

156 River, was so high that we could not determine it with ${ }^{210} \mathrm{~Pb}$ in a $50-\mathrm{cm}$ core. Since we

157 were unable to determine the amount of time represented by the core, we only measured

158 contaminants at a few depths. Consequently, core GVRD-4 only appears on plots

159 showing surface concentrations and not depth profiles or fluxes.) In contrast, PBDE

160 profiles imply a pervasive rapid increase toward the sediment surface. Already in some

161 parts of the world, the flux of PBDEs has overtaken that of PCBs. For example, the

162 atmospheric flux of PBDEs to the Baltic Sea is estimated at almost 40 times that of PCBs

163 (Law et al., 2006).

165 The range of Total PCB concentration values in surface sediments $(0-1 \mathrm{~cm}$ depth, or 1 -

$1662 \mathrm{~cm}$ in core GVRD-4) is similar to that of Total PBDEs (Table 2), but the two classes of

167 chemical do not have the same spatial distribution at the surface (Fig. 6a). The

168 concentration of PCBs is highest in the northern Strait (core GVRD-1), where there is no

169 obvious local source, and near the mouth of Vancouver Harbour (GVRD- 2). It is low in

170 the central Strait, near the mouth of the Fraser River. In contrast, the concentration of

171 PBDEs near the Iona Island wastewater outfall (GVRD-3, 12,700 pg/g) dwarfs that

172 measured anywhere else in the Strait (range 270-1800 pg/g). Clearly, the distributions of

173 the two contaminants are determined by different factors.

175 The 10-year inventory at each site shows a different pattern than does surface

176 concentration (c.f. Figs. 6a and 6b), offering a clue to the cause of the distribution

177 observed in the surface concentration plot. Although the northern Strait (core GVRD-1) 
178 has the highest surface concentration of PCBs, for example, the 10-year inventory of

179 PCBs at that station is relatively low (Table 2, Fig. 6). The highest inventories of PCBs

180 are found at stations GVRD-6 and GVRD-3 in the southern Strait, which have the highest

181 sediment accumulation rates of the set. Station GVRD-4, near the mouth of the Fraser

182 River, probably has the very highest inventory, but we were unable to calculate it,

183 because, as mentioned above, the sediment accumulation rate at that site was too high.

184 The spatial pattern in the 10-year inventory of PBDEs is similar to that of the PCBs (Fig.

185 6), except that the inventory of PBDEs is very high at station GVRD-3, near the

186 wastewater outfall. Excluding PBDEs at that station, the inventories of both classes of

187 contaminants are strongly positively related to the sediment accumulation rate (Fig. 7).

188 However, the surface concentration is not. There is no significant correlation between

189 surface concentration of PCBs or PBDEs and sediment accumulation rate (data not

190 shown).

191

192 The measured surface concentration of a contaminant is strongly influenced by the local

193 sediment accumulation and mixing rates (e.g. Johannessen et al., 2005). The sediment

194 accumulation rate is much lower in the northern Strait of Georgia than near the mouth of

195 the Fraser River, which supplies about $80 \%$ of the sediment to the Strait (Luternauer et

196 al., 1983). We infer that the concentration of PCBs in surface sediment is lower at the

197 southern stations near the mouth of the Fraser River than in the northern Strait, because

198 the inorganic particles discharged near these southern stations tends to dilute the sediment

199 contaminant burden. 
201 Benthic mixing compounds the effect of sedimentation rate on the observed surface

202 concentration of PCBs. In the more recent (shallow) sections of the cores, the PCB

203 concentration decreases toward the sediment surface because the discharge and flux to

204 sediments was at its highest during the 1960s and 70s. When organisms mix the surface

205 sediments, they tend to move the more contaminated, older sediment up into the less

206 contaminated, post-1970 deposits. In an area like the northern Strait, which has a low

207 sediment accumulation rate, the sediment that is mixed to the surface dates more closely

208 to the PCB maximum and is, therefore, more contaminated than that mixed to the surface

209 in an area with a higher sedimentation rate.

211 Because the PBDE concentration increases toward the surface, mixing has the opposite

212 effect on its surface value than on that of PCBs. Older sediment mixed up to the surface

213 has a lower concentration of PBDEs than the recent material, so the concentration of

214 PBDEs measured at the surface of the sediments is lower than that in the particles

215 currently accumulating. However, the surface concentration of PBDEs shows no

216 relationship with sediment accumulation rate, even if it is normalized to the mixing rate

217 (data not shown). Because of the recency of their arrival in this environment, PBDEs are

218 still mainly concentrated near their sources. The linear relationship between sediment

219 accumulation rate and the 10-year inventory of PBDEs shown in Fig. 7 implies an

220 average concentration of PBDEs on particles deposited over the last ten years that is the

221 same throughout the study area $(\sim 660 \mathrm{pg} / \mathrm{g}$, from the slope of the regression line), except

222 at the outfall station. 
224 A study of the concentrations of PCBs and PBDEs in fish from remote European

225 mountain lakes (Gallego et al., 2007) similarly illustrated the importance of both history

226 of emissions and environmental distribution processes. Gallego et al. (2007) showed that

227 the concentration gradients of PCBS and PBDEs were directly related to temperature and

228 to one another in the Pyrenees mountains, near long-standing sources of PBDEs, while, in

229 the Tatras mountains, near newer sources of PBDEs, PCBs were still related to

230 temperature, but PBDEs were not. They inferred from these observations that PCBs had

231 had much longer to be redistributed by environmental processes like seasonal temperature

232 cycling. Similarly, Spanish coastal sediments (Eljarrat et al., 2005) show correlations

233 between PCBs and dioxin-like compounds but not PBDEs, except near the mouth of the

234 river, which is likely a current pathway of PBDEs into that environment.

236 In the Strait of Georgia, the concentrations of PBDEs are highest near the wastewater

237 outfall (GVRD-3, Table 2, Fig. 2). Work in other environments has similarly shown that

238 the highest concentrations of PBDEs in sediment occur near industrial (particularly textile

239 industries) and domestic wastewater discharges (e.g. Gevao et al., 2006; Law et al., 2006;

240 Samara et al., 2006). The concentration of total PBDE measured in the effluent from the

241 Iona Island wastewater treatment plant in 2002-2005 was 61 - $432 \mathrm{ng} / \mathrm{L}$ (Metro

242 Vancouver. Municipal Wastewater Effluent Characterization. Metro Vancouver,

243 Burnaby, B. C., in prep.), which is higher than that in local river or sea water (lower

244 Fraser River $0.2-1.8$ ng/L in 2004-2006, Environment Canada, 2007, unpublished data,

245 southern Strait of Georgia seawater $0.01-0.02 \mathrm{ng} / \mathrm{L}$ Dangerfield et al., 2007). PBDEs

246 have been measured in high concentration in house dust in Canada and other countries 
247 (e.g. Jones-Otazo et al., 2005; Wilford et al., 2005), and their high concentration in

248 wastewater likely reflects the ubiquitous use of flame retardants on household furniture,

249 electronics and toys.

251 In contrast to PBDEs, PCBs are not actively used in homes or industry in Canada any

252 more, although there is still relict PCB-containing equipment left, such as some

253 transformers (Environment Canada, 2007, http://www.ec.gc.ca/wmd-

$254 \mathrm{dgd} / \mathrm{default} . \mathrm{asp}$ ?lang=En\&n=13426772-1), and they are still found pervasively in the

255 environment. Accordingly, the sediments near the outfall record PBDEs and PCBs

256 differently. Accounting for sediment accumulation and mixing, the best fit model of PCB

257 deposition (see Section 2) requires a sudden decrease in the concentration of PCBs in the

258 particles falling onto that site in 1989, the year after the deep water outfall was opened

259 (Fig. 8). PCBs, which are ubiquitously associated with organic matter, are discharged

260 with effluent from the outfall. Concentrations of PCBs in effluent are set by the present

261 PCB background in material entering the treatment plant, and their concentration in the

262 local effluent (9.3-17.4 ng/L, Metro Vancouver, in prep.) is lower than that of PBDEs.

263 Accordingly, the increased load of particles from effluent discharged near GVRD-3

264 appears to have diluted the flux of PCBs while at the same time increasing the load of

265 PBDEs.

267 The core collected at the entrance to Vancouver Harbour (GVRD-2) also shows

268 significant contamination by PCBs and PBDEs (Fig. 6, Table 2). The concentration of

269 PCBs is higher there than at the outfall station (GVRD-3), while that of PBDEs is lower. 
270 There probably is a source of PBDEs bordering the harbour. This sediment core study

271 did not extend into the harbour, but independent measurements show a surface sediment

272 PBDE concentration there similar to that measured near the outfall (Peter Ross,

273 unpublished data, 2007.) Since the sediment accumulation rate is much lower inside the

274 harbour (0.19 g cm-2 yr-1, Johannessen et al., 2003) than near the Iona Island outfall (1.3

$\left.275 \mathrm{~g} \mathrm{~cm}^{-2} \mathrm{yr}^{-1}\right)$, the flux of PBDEs must be lower there too.

277 Regardless of the actual fluxes to the sediments, benthic organisms are exposed to

278 contaminants, including PCBs, in proportion to concentration (e.g. Reynoldson, 1987).

279 Consequently, some of the areas of the Strait with the lowest contaminant fluxes may

280 actually be the major points of contaminant entry into the food chain from the sediments.

281 This would be particularly true of PCBs, which are in high concentration where the flux

282 is low, for example in the northern Strait. The highest flux and concentration of PBDEs

283 currently occur together, although that likely will change in the future, after PBDE use is

284 curtailed, and environmental cycling begins to dominate the transport processes as has

285 occurred with PCBs. Even the highest concentration of PCBs measured in these

286 sediments is well below that given as the Interim Sediment Quality Guideline (maximum

$2872910 \mathrm{pg} / \mathrm{g}$ outside Vancouver Harbour vs. guideline 21,500 pg/g, CCME, 2001), and the

288 PCB concentration will continue to decrease, in the absence of a new source. There are

289 no sediment quality guidelines for PBDEs, but, for comparison, the concentration of

290 PBDEs in sediment near the Iona Island outfall $(12,800 \mathrm{pg} / \mathrm{g})$ is already more than half

291 the PCB guideline level and increasing rapidly. 
293 So far we have only discussed Total PCBs and Total PBDEs, but each class of chemical

294 is made up of 209 possible congeners. PCBs and PBDEs can be considered in

295 homologue groups, that is, groups of congeners with the same number of chlorine or

296 bromine atoms. The PCB homologues are distributed with a peak in the mid-weight

297 range (Fig. 9a), reflecting the proportions in which the various congeners were used and

298 the number of congeners in each homologue group. This pattern is similar to the

299 distribution found in other environments and organisms (e.g. Ross et al., 2000). The

300 PBDEs, however, while theoretically comprising the same number of congeners per

301 homologue as the PCBs, are dominated by deca-BDE (Fig. 9b). This formulation,

302 composed principally of BDE-209, is the only form still on the market in North America.

303 It has an extremely strong affinity for particles (e.g. Law et al., 2006). The next most

304 highly concentrated congeners measured in this study are BDE-47, 99 and 100. These

305 four congeners are predominant in sediments almost everywhere that PBDEs have been

306 measured (De Wit, 2002; Eljarrat et al., 2005). BDE-47, 99 and 100, (but not BDE-209,

307 probably because it is less easily bioaccumulated) also predominate in the biota (De Wit,

308 2002). These congeners are usually interpreted to represent a mixture of the deca- and

309 penta- formulations. However, one exception is in the coastal sediments off Kuwait,

310 where high atmospheric temperatures (annual range $10-50^{\circ} \mathrm{C}$ over land) cause most of the

311 lighter congeners to remain gaseous, and the sediment pattern is dominated by BDE-183,

312 an indicator of the octa formulation that is in use in that country (Gevao et al., 2006.)

314 There has been increasing interest in the debromination of deca-BDE (mainly BDE-209)

315 to lighter, more toxic forms, in the environment. As de Boer et al. (2003) point out, 
316 debromination of even a very small proportion of deca-BDE in the marine environment

317 would result in significant contamination by the more toxic congeners, because of the

318 high flux of deca-BDE. In laboratory experiments, deca-BDE has been shown to

319 debrominate on exposure to ultraviolet radiation (Eriksson et al., 2004) or zerovalent iron

320 (Keum and Li, 2005). Debromination is stepwise, one $\mathrm{Br}$ substitution at a time, and

321 products include all homologue groups from nona-BDE to mono-BDE. In laboratory

322 conditions the debromination occurs on the time scale of minutes to weeks, depending on

323 the product measured and on the medium in which the deca-BDE is dissolved (Eriksson

324 et al., 2004; Keum and Li, 2005). Environmental rates of debromination and the

325 distribution of products is unknown, so we did not know which homologues to expect to

326 find in this environment as the end products of debromination. Consequently, we

327 considered changes in the ratios of deca-BDE to all homologue groups as possible

328 indicators of debromination.

330 To compare congener ratios down-core in all the cores, with their different sedimentation

331 rates, we calculated a time scale for each core as the depth of each measurement divided

332 by that core's sedimentation rate. This quotient does not represent exact years before

333 present because of the extensive benthic mixing of the surface sediment, but it does allow

334 a comparison among cores over approximately equivalent time scales. On this common

335 time scale we plotted the ratio of the sum of the five most abundant congeners (BDE-209,

$336-47,-49,-99,-100)$ to BDE-209 for each sediment core (Fig. 10a). If debromination were

337 occurring in the sediment, we would expect to see an increase in the BDE ratio downcore,

338 as the lighter congeners were formed from the heavy ones. Confounding this prediction, 
339 we would expect the same trend as a result of the pattern of use over time, as the

340 commercial deca formulation has become more dominant. However, Fig. 10 does not

341 show that pattern. An average of the two profiles that extend the furthest back in time

342 shows at best a flat profile. If all the cores were included, the trend would be opposite to

343 that expected for both debromination and changes in usage.

345 Because we can interpret the sediment cores on a time scale of years to decades, while

346 laboratory results suggest a much shorter half life for deca-BDE, it is possible that the

347 debromination occurs in the environment before the BDEs reach the sediments. We

348 compared the ratios of individual homologues to deca-BDE in effluent from the Iona

349 Island wastewater treatment plant (2002-2005, Metro Vancouver, in prep.) with those in

350 the sediment traps moored nearby (2003-2004; see Section 2) and those in the sediment

351 cores (collected in 2003). (The mono-, hepta- and octa-BDE homologue groups were

352 frequently undetectable in our samples and were excluded from this calculation.) If

353 debromination had occurred between the effluent and the traps or between the traps (in

354 the water column) and the bottom sediment, we would expect to see the homologue ratios

355 increasing from effluent to traps to surface sediment to sediment averaged over the depth

356 range for which BDE-209 was detectable. Such a pattern in not discernable (Fig. 10b),

357 except possibly for the ratio of nona- to deca-BDE. The apparent increase in the nona-to

358 deca-BDE ratio between the effluent and the sediments might indicate debromination that

359 occurs more slowly in the environment than in the laboratory because of the low intensity

360 of light where the wastewater is discharged (80 m water depth) and the absence of strong 
361 reducing agents in the water column. However, it is not clear whether the increase is

362 environmentally significant.

364 The ratio of the sum of PBDEs to BDE 209 in surface sediments is lowest near the

365 wastewater outfall (GVRD-3) and in the remote northern Strait (GVRD-1), showing

366 greater dominance by BDE-209 at those sites. The higher proportion of BDE-209 near

367 the outfall is not surprising, because that congener's affinity for particles makes it likely

368 to drop out preferentially near the source. If all the other sites had proportionately less

369 BDE-209, the distribution could even be evidence of environmental debromination

370 during the movement through the Strait. However, the high proportion of BDE-209 in

371 the northern Strait is puzzling. Possibly BDE-209 is transported on dust and does not

372 sink until it gets packaged, whereas the lighter BDEs are partitioned into larger, organic-

373 rich particles like zooplankton. This would imply that the dust-bound material could

374 travel farther in water than the larger organic particles. A comparison of congener ratios

375 among a larger number of cores might help to resolve this question.

378 4. Conclusion

379 PCBs and PBDEs both are persistent, have or have had local and long-range

380 anthropogenic sources, and have entered a geochemically identical sedimentary regime in

381 the Strait of Georgia. Nevertheless, their distribution in the sediments of the Strait of

382 Georgia differs due to the differing stages in their emission histories. From 1930 until the

383 early 1980s, PCBs were loaded into environmental reservoirs where they have been 
384 sorted and redistributed by secondary environmental processes, including volatilization

385 and organic carbon cycling. The amounts cycling are gradually reducing as burial,

386 metabolism and degradation occur, but their cycle is presently controlled by exchanges in

387 which loss from one environmental compartment is accompanied by gain in another. The

388 current distribution of PCBs in Strait of Georgia sediments is largely controlled by

389 sediment flux, bio-mixing and organic/inorganic geochemistry. PCB concentration is

390 high where the flux of diluting, inorganic sediment is low; where the depth of benthic

391 mixing is high, bringing older, more highly contaminated sediment to the surface; and

392 where the concentration of organic carbon, for which PCBs have an affinity, is high.

394 In contrast, PBDEs are relatively new to the system and growing in importance. Their

395 distribution is strongly controlled by current sources and use patterns; in particular, the

396 entry of these chemicals into domestic dust through the use of treated fabric supports the

397 efficient transport of these compounds to the coastal ocean by municipal wastewater

398 systems. At present the range of surface concentration is similar for the two

399 contaminants, but with PCBs decreasing and PBDEs increasing we expect the latter to

400 predominate in the next decade.

401

402 The PBDEs are dominated by BDE-209, and environmental debromination in sediments

403 is not evident. There may be a slight increase in the proportion of nona- to deca-BDE

404 between the effluent and the sediment cores, but more data are required to demonstrate

405 that trend conclusively.

406 
407 PBDE emissions are repeating the experience with PCBs, such that we are now at the 408 same point reached for PCBs in the late 1960s. PBDE discharge continues to increase, 409 and these compounds continue to load into all compartments of the environment. The

410 experience with PCBs suggests that once the discharge of PBDEs stops, there will be a 411 period of readjustment in the sediments that will change the pattern of surface

412 concentration and exposure of the benthos. Eventually, inorganic sediment will bury the 413 PBDEs, but that will take decades after the end of the discharge. 


\section{Acknowledgements}

415 The authors thank Dr. Peter Ross for his useful insight into the interpretation presented

416 here and Mary O'Brien and Darren Tuele for technical assistance with the sediment traps

417 and cores. We appreciate the assistance of the officers and crew of the CCGS Vector.

418 Flett Research Ltd., in Winnipeg, Canada measured radioisotopes in the sediment cores,

419 which allowed us to calculate the sedimentation and mixing rates. AXYS Analytical Ltd.

420 in Sidney, Canada measured PCBs and PBDEs in the core and trap samples. Dr. Susan

421 Roe of Environment Canada sent and explained the Sediment Quality Guidelines for

422 PCBs. Funding for this work was provided by a collaborative agreement with Metro

423 Vancouver (formerly the Greater Vancouver Regional District) as part of the Strait of

424 Georgia Ambient Monitoring Program, by Environment Canada, through the Georgia

425 Basin Action Plan, and by Fisheries and Oceans Canada. 


\section{References}

427 Alaee, M. (2006). Recent progress in understanding of the levels, trends, fate and effects of BFRs in the environment. Chemosphere, 64,

429 Calvert, S.E. and Pedersen, T.F. (1995). On the organic carbon maximum on the continental slope of the eastern Arabian Sea. Journal of Marine Research, 53, 269296.

CCME (2001). Canadian sediment quality guidelines for the protection of aquatic life: Polychlorinated biphenyls (PCBs). Updated. In Canadian Environmental Quality Guidelines, 1999, Canadian Council of Ministers of the Environment, Winnipeg. retardants threaten ocean life? Nature, 394, 28-29.

de Boer, J., Wester, P.G., van der Horst, A. and Leonards, P.E.G. (2003). Polybrominated

444 De Wit, C.A. (2002). An overview of brominated flame retardants in the environment. Chemosphere, 46, 583-624.

446 Eakins, J.D. and Morrison, R.T. (1978). A new procedure for the determination of lead210 in lake and marine sediments. International Journal of Applied Radiation and Isotopes, 29, 531-536. 
449 Eljarrat, E., de la Cal, A., Larrazabul, D., Fabrellas, B., Fernandez-Alba, A.R., Borrull,

450 F., Marce, R.M. and Barcelo, D. (2005). Occurrence of polybrominated diphenylethers, polychlorinated dibenzo-p-dioxins, dibenzofurans and biphenyls in coastal sediments from Spain. Environmental Pollution, 136, 493-501.

Elliott, J.E., Wilson, L.K. and Wakeford, B. (2005). Polybrominated diphenyl ether trends in eggs of marine and freshwater birds from British Columbia, Canada, 1979-2002. Environmental Science and Technology, 39, 5584-5591.

EPA (2003a). EPA Method 1668, Revision A - Chlorinated biphenyl congeners in water, soil, sediment, biosolids, and tissue by HRGC/HRMS, with changes and corrections through to August 20, 2003.

EPA (2003b). EPA Method 1614. Brominated diphenyl ethers in water, soil, sediment, and tissue by HRGC/HRMS. Draft August, 2003.

Eriksson, J., Green, N., Marsh, G. and Bergman, Å. (2004). Photochemical decomposition of 15 polybrominated diphenyl ether congeners in methanol / water. Environmental Science and Technology, 38, 3119-3125.

Gallego, E., Grimalt, J.O., Bartrons, M., Lopez, J.F., Camarero, L., Catalan, J., Stuchlik, from European high mountain lakes. Environmental Science and Technology, 41, 2196-2202.

Gevao, B., Beg, M.U., Al-Ghadban, A.N., Al-Omair, A., Helaleh, M. and Zafar, J. (2006). Spatial distribution of polybrominated diphenyl ethers in coastal marine sediments receiving industrial and municipal effluents in Kuwait. Chemosphere, 62, 1078-1086. 
472 Guinasso, N.L. and Schink, D.R. (1975). Quantitative estimates of biological mixing

473 rates in abyssal sediments. Journal of Geophysical Research, 80, 3032-3043.

474 Hickie, B.E., Ross, P.S., Macdonald, R.W. and Ford, J.K.B. (2007). Killer whales

475 (Orcinus orca) face protracted health risks associated with lifetime exposure to 476 PCBs. Environmental Science and Technology, in press,

477 Ikonomou, M.G., Fernandez, M.P. and Hickman, Z.L. (2006). Spatio-temporal and 478 species-specific variation in PBDE levels / patterns in British Columbia's coastal waters. Environmental Pollution, 140, 355-363.

480 Johannessen, S.C., Macdonald, R.W. and Eek, M.K. (2005). Historical trends in mercury 481 sedimentation and mixing in the Strait of Georgia, Canada. Environmental

483 Johannessen, S.C., Macdonald, R.W. and Paton, D.W. (2003). A sediment and organic 484 carbon budget for the greater Strait of Georgia. Estuarine, Coastal and Shelf Science, 56, 845-860.

Jones-Otazo, H.A., Clarke, J.P., Diamond, M.L., Archbold, J.A., Ferguson, G., Harner,

490 Keum, Y.-S. and Li, Q.X. (2005). Reductive debromination of polybrominated diphenyl 491 ethers by zerovalent iron. Environmental Science and Technology, 39, 2280-2286.

492 Lavelle, J.W., Massoth, G.J. and Crecelius, E.A. (1986). Accumulation rates of recent 493 sediments in Puget Sound, Washington. Marine Geology, 72, 59-70. 
494 Law, R.J., Allchin, C.R., de Boer, J., Covaci, A., Herzke, D., Lepom, P., Morris, S.,

495 Tronczynski, J. and de Wit, C.A. (2006). Levels and trends of brominated flame

496 retardants in the European environment. Chemosphere, 64, 187-208.

497 Li, A., Rockne, K.J., Sturchio, N., Song, W., Ford, J.C., Buckley, D.R. and Mills, W.J.

498 (2006). Polybrominated diphenyl ethers in the sediments of the Great Lakes. 4.

499 Influencing factors, trends, and implications. Environmental Science and

$500 \quad$ Technology, 40, 7528-7534.

501 Luternauer, J.L., Clague, J.J. and Pharo, C.H. (1983). Substrates of the Strait of Georgia,

502 British Columbia. Canadian Journal of Fisheries and Aquatic Sciences, 40, 1026-

$503 \quad 1032$.

504 Macdonald, R.W., Barrie, L.A., Bidleman, T.F., Diamond, M.L., Gregor, D.J., Semkin, 505 R.G., Strachan, W.M.J., Li, Y.F., Wania, F., Alaee, M., Alexeeva, L.B., Backus,

512 Macdonald, R.W., Cretney, W.J., Crewe, N. and Paton, D. (1992). A history of

513 octachlordibenzo-p-dioxin, 2,3,7,8-tetrachlorodibenzofuran, and 3,3',4,4'-

514 tetrachlorobiphenyl contamination in Howe Sound, British Columbia.

515 Environmental Science and Technology, 26, 1544-550. 
516 Macdonald, R.W., Macdonald, D.M., O'Brien, M.O. and Gobeil, C. (1991). Accumulation of heavy metals $(\mathrm{Pb}, \mathrm{Zn}, \mathrm{Cu}, \mathrm{Cd})$, carbon and nitrogen in sediments from Strait of Georgia, B.C., Canada. Marine Chemistry, 34, 109-135.

519 Martin, M., Lam, P.K.S. and Richardson, B.J. (2004). An Asian quandary: where have all 520 of the PBDEs gone? Marine Pollution Bulletin, 49, 375-382.

521 Rapaport, R.A. and Eisenreich, S.J. (1988). Historical atmospheric inputs of high molecular weight chlorinated hydrocarbons to eastern North America. Environmental Science and Technology, 22, 931-941.

524 Reynoldson, T.B. (1987). Interactions between sediment contaminants and benthic organisms. Hydrobiologia, 149, 53-66.

526 Robbins, J.A. (1978). Geochemical and geophysical applications of radioactive lead. Nriagu (Eds.). The Biogeochemistry of Lead in the Environment. Elsevier / North-Holland Biomedical Press, 285-393 pp.

Ross, P.S. (2006). Fireproof killer whales (Orcinus orca): flame-retardant chemicals and the conservation imperative in the charismatic icon of British Columbia, Canada.

532 Ross, P.S., Ellis, G.M., Ikonomou, M.G., Barrett-Lennard, L.G. and Addison, R.F. (2000). High PCB concentrations in free-ranging Pacific killer whales, Orcinus

536 Samara, F., Tsai, C.W. and Aga, D.S. (2006). Determination of potential sources of PCBs orca: Effects of age, sex and dietary preference. Marine Pollution Bulletin, 40, and PBDEs in sediments of the Niagara River. Environmental Pollution, 139, 489-497. 
539 Shang, D.Y., Macdonald, R.W. and Ikonomou, M.G. (1999). Persistence of nonylphenol

540 ethoxylate surfactants and their primary degradation products in sediments from

541 near a municipal outfall in the Strait of Georgia, British Columbia, Canada.

542 Environmental Science and Technology, 33, 1366-1372.

543 Wania, F. and Dugani, C.B. (2003). Assessing the long-range transport potential of

544 polybrominated diphenyl ethers: A comparison of four multimedia models.

$545 \quad$ Environmental Toxicology and Chemistry, 22, 1252-1261.

546 Wilford, B.H., Shoeib, M., Harner, T., Zhu, J. and Jones, K.C. (2005). Polybrominated

547 diphenyl ethers in indoor dust in Ottawa, Canada: implications for sources and

$548 \quad$ exposure. Environmental Science and Technology, 39, 7027-7035.

549 Yunker, M.B. and Macdonald, R.W. (2003). Alkane and PAH depositional history, 550 sources and fluxes in sediments from the Fraser River Basin and Strait of Georgia.

$551 \quad$ Environmental Toxicology and Chemistry, 34, 1429-1454. 


\begin{tabular}{|c|c|c|c|c|c|}
\hline Core name & $\begin{array}{c}\text { Sedimentation } \\
\text { velocity } \\
\left(\mathrm{cm} \mathrm{yr}^{-1}\right)\end{array}$ & $\begin{array}{c}\text { Sediment } \\
\text { accumulation } \\
\text { rate } \\
\left(\mathrm{g} \mathrm{cm}^{-2} \mathbf{y r}^{-1}\right)\end{array}$ & $\begin{array}{c}\text { Surface mixed } \\
\text { layer depth } \\
(\mathrm{cm})\end{array}$ & $\begin{array}{c}\text { Mixing rate in } \\
\text { upper layer } \\
\left(\mathrm{cm}^{2} \mathrm{yr}^{-1}\right)\end{array}$ & $\begin{array}{c}\text { Mixing rate in } \\
\text { lower layer } \\
\left(\mathrm{cm}^{2} \mathrm{yr}^{-1}\right)\end{array}$ \\
\hline GVRD-1 & 0.25 & 0.078 & 7 & 3 & 0.01 \\
\hline GVRD-2 & 0.35 & 0.26 & 10 & 15 & 0.01 \\
\hline $\begin{array}{c}\text { GVRD-3 } \\
\text { (outfall) }\end{array}$ & 1.2 & 1.3 & 7 & 20 & 0.01 \\
\hline GVRD-4 & unknown $(>3)$ & unknown (> 3) & unknown & unknown & unknown \\
\hline GVRD-5 & 1.1 & 0.64 & 10 & 5 & 0.01 \\
\hline GVRD-6 & 2.9 & 2.7 & 12 & 30 & 0.01 \\
\hline GVRD-7 & 0.30 & 0.32 & 12 & 0.5 & 0.01 \\
\hline
\end{tabular}

Table 1. Sedimentation parameters in sediment cores determined using $\mathrm{Pb}-210$ and an advective-diffusive mixing model. See Fig. 1 for core collection locations. The sediment accumulation rate in core GVRD-3 appears to have increased significantly about 15 years ago. The sedimentation and mixing rates for core GVRD-4 could not be determined from 


\begin{tabular}{lllll} 
Station & $\begin{array}{l}\text { [Total } \\
\text { PCB] } \\
\text { at surface } \\
(\mathbf{p g} / \mathbf{g})\end{array}$ & $\begin{array}{l}\text { [Total } \\
\text { PBDE] } \\
\text { at surface } \\
(\mathbf{p g} / \mathbf{g})\end{array}$ & $\begin{array}{l}\mathbf{1 0 - y r} \\
\text { inventory } \\
\text { of PCB } \\
\left(\mathbf{p g} / \mathbf{c m}^{2}\right)\end{array}$ & $\begin{array}{l}\mathbf{1 0 - y r} \\
\text { inventory } \\
\text { of PBDE } \\
\left(\mathbf{p g} / \mathbf{c m}^{\mathbf{2}}\right)\end{array}$ \\
\hline GVRD-1 & 2360 & 671 & 1400 & 400 \\
GVRD-2 & 2910 & 1793 & 11200 & 4700 \\
GVRD-3 & 1210 & 12647 & 18450 & 109600 \\
GVRD-4 & 484 & 1105 & unknown & unknown \\
GVRD-5 & 1120 & 539 & 8560 & 5500 \\
GVRD-6 & 668 & 728 & 70260 & 18400 \\
GVRD-7 & 507 & 271 & 1330 & 840
\end{tabular}

Table 2. Concentrations of selected components of surface sediments and 10-year inventories of total PCBs and total PBDEs. The inventory does not represent exactly 10

566 years, because benthic organisms mix the surface sediments. The inventory for each core 567 was calculated by multiplying the sedimentation rate by 10 years and summing the 568 contaminants over the resulting depth. It was not possible to calculate the inventory for 569 station 4, because the sedimentation rate is unknown, and we did not analyze all the depth 570 sections for contaminants. 


\section{List of Figures}

603

604

605

606

607

608

609

610

611

612

613

614

615

616

Fig. 1. Emission histories of PCBs and PBDEs, modified from Li et al., 2006 (North American PBDE emission trend) and Rapaport et al., 1988 (\% of cumulative emissions of PCBs to Eastern North America) The last five years of the PCB trend (dotted) represent an extrapolation of Rapaport's polynomial fit beyond the date of its publication.

Fig. 2. Sediment core sampling locations (GVRD-1 to GVRD-7) and locations of sediment trap moorings (GVRD-A1, GVRD-B1) in the Strait of Georgia. The black line immediately to the east of station GVRD-3 represents the location of the Iona Island outfall pipe.

Fig. 3. Profiles of the natural $\log$ of the activity of excess ${ }^{210} \mathrm{~Pb}$ in the sediment cores. Dots represent data, solid lines, the accumulation and mixing model, and dotted, horizontal lines, the bottom of the surface mixed layer for each core.

Fig. 4. Profiles of the concentration of (a) total PCB and (b) total PBDE in all sediment cores.

Fig. 5. Profiles of the concentration of (a) total PCB and (b) total PBDE in sediment core GVRD-1. This core was chosen, because its low sediment accumulation rate means that the entire history of PCB contamination is visible in the $50 \mathrm{~cm}$ core. All the cores show the same trends, although they do not all represent the same amount of time. (See Table 1 for sediment accumulation rates.) Error bars are $\pm 20 \%$, the measurement uncertainty reported by the analytical laboratory.

Fig. 6. Distribution of total PCBs and total PBDEs in Strait of Georgia sediments: (a) surface concentration, (b) 10-year inventory, as described in text.

Fig. 7. Relationship between the 10-year inventories of (a) total PCB and (b) total PBDE vs. sediment accumulation rate. In panel $b$, the value for station GVRD-3, near the Iona Island wastewater outfall, is not included in the regression.

Fig. 8. Profile of the concentration of Total PCB in sediment core GVRD-3, collected near the Iona Island outfall, with the model fit shown as the solid line. The model only fits the data with a sudden decrease in the PCB concentration of the incident particles in 1989. Error bars are $\pm 20 \%$, the measurement uncertainty reported by the analytical laboratory.

Fig. 9. Homologue distribution in surface sediments averaged over all 7 stations. Because the range of concentrations was so wide, each station's values were meanweighted over all homologues, to preserve the shape of the distribution while giving equal weight to all stations.

Fig. 10. (a) Ratio of the sum of the five most abundant congeners (BDE-209, 47, 49, 99, 100) to BDE-209 in sediment cores. The horizontal axis represents a time scale 
617 calculated as the measurement depth divided by the sedimentation velocity. This does 618 not represent actual years before present, because of benthic mixing, but it is an 619 approximately common time scale for all stations. The heavy black line represents the 620 average of the BDE ratios measured in the two cores that represent the longest time 621 (GVRD-1 and GVRD-2). On this plot, debromination would appear as an increase in the 622 BDE ratio with increasing depth. It is not evident in these data.

623 (b) Homologue ratios in wastewater treatment plant effluent, sediment trap particulates 624 and sediment cores. 
Figure

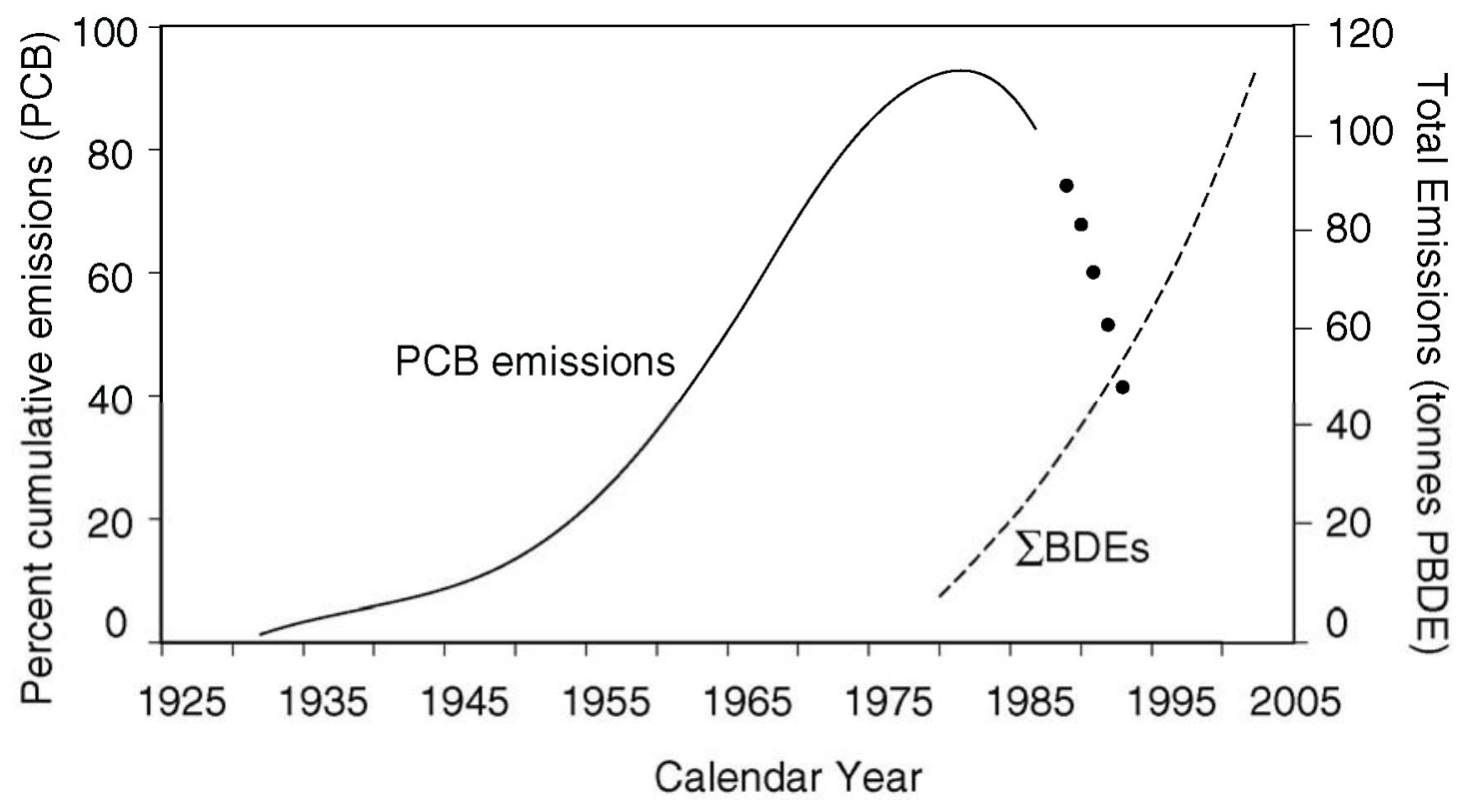


Figure

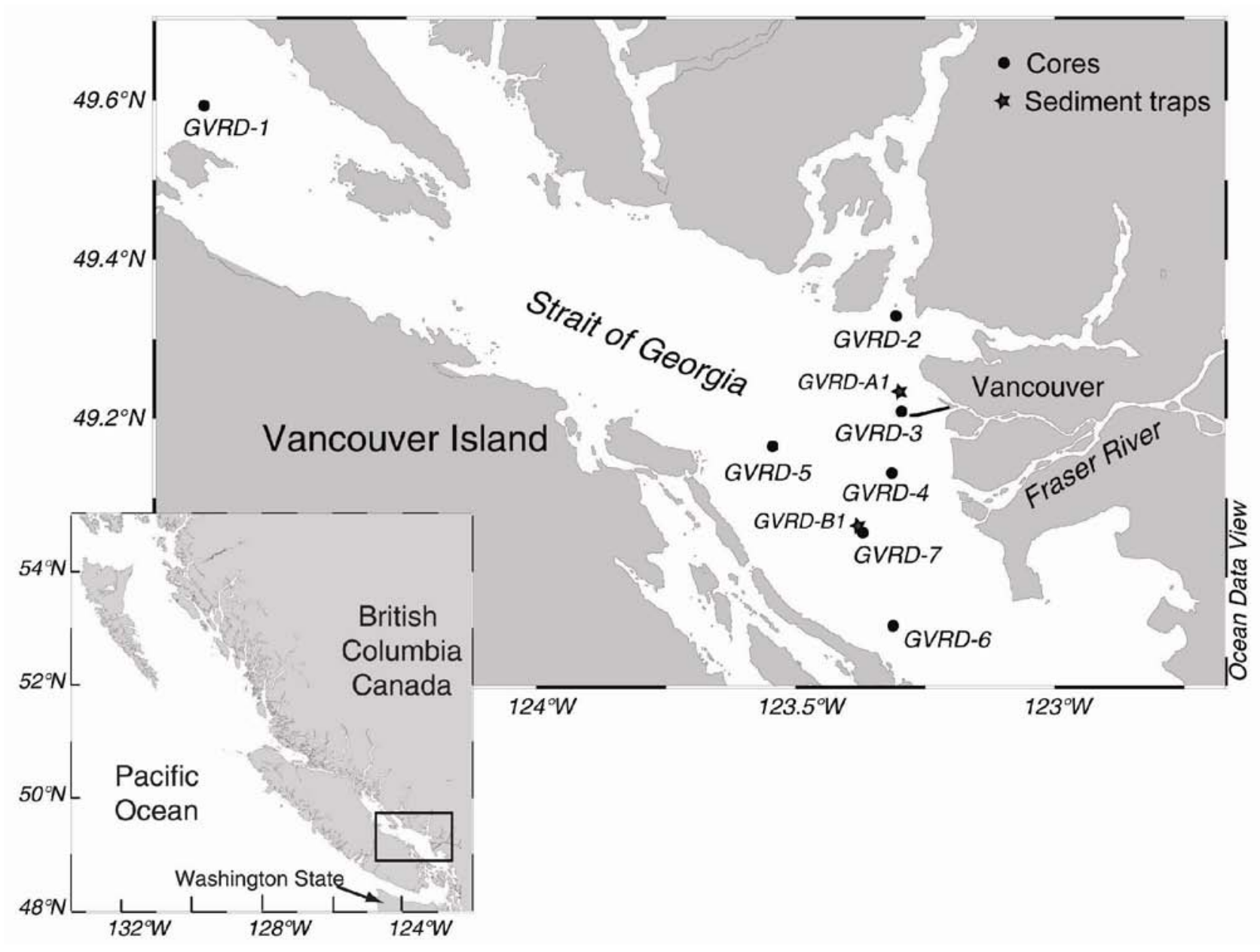




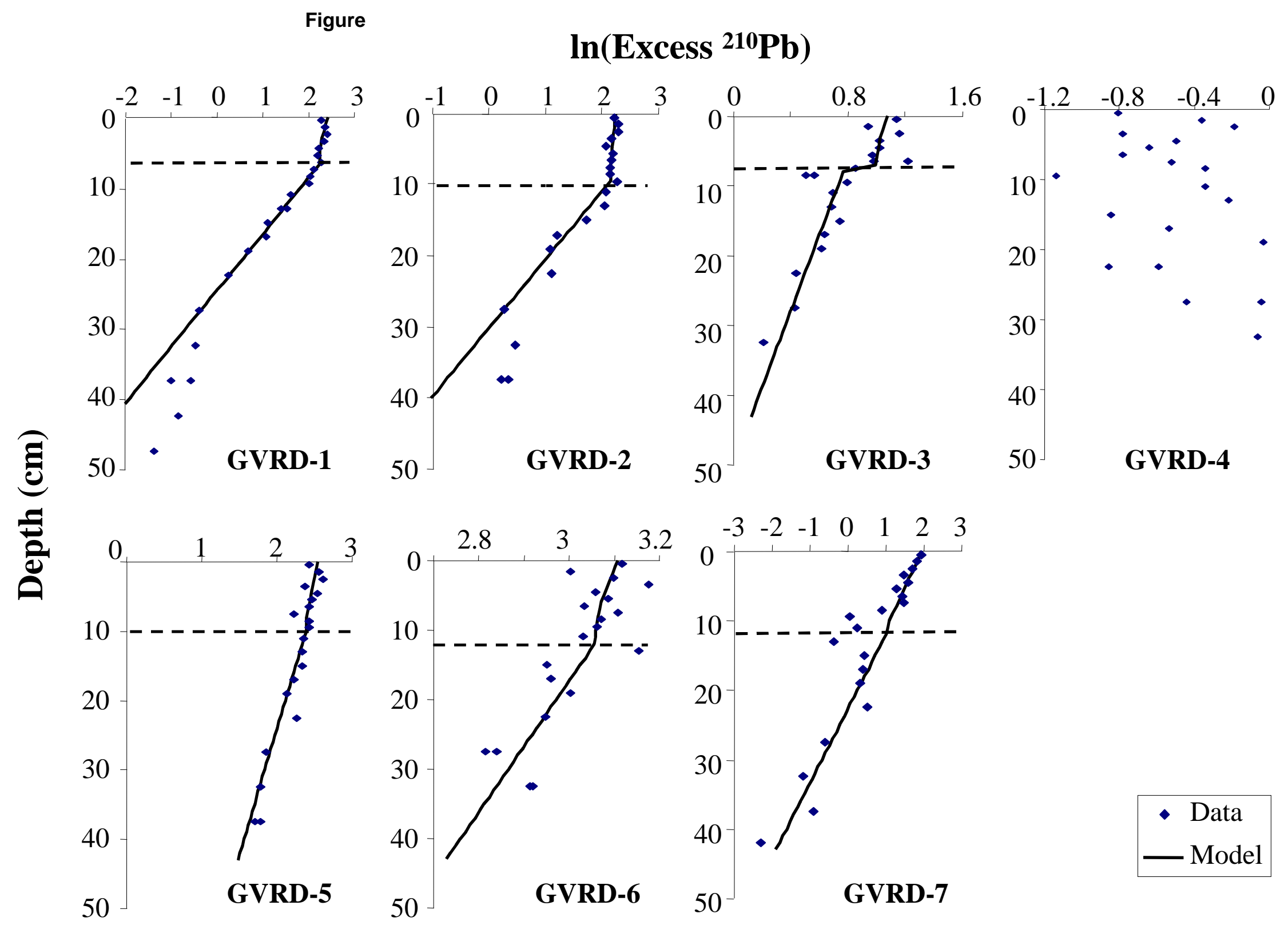


Figure

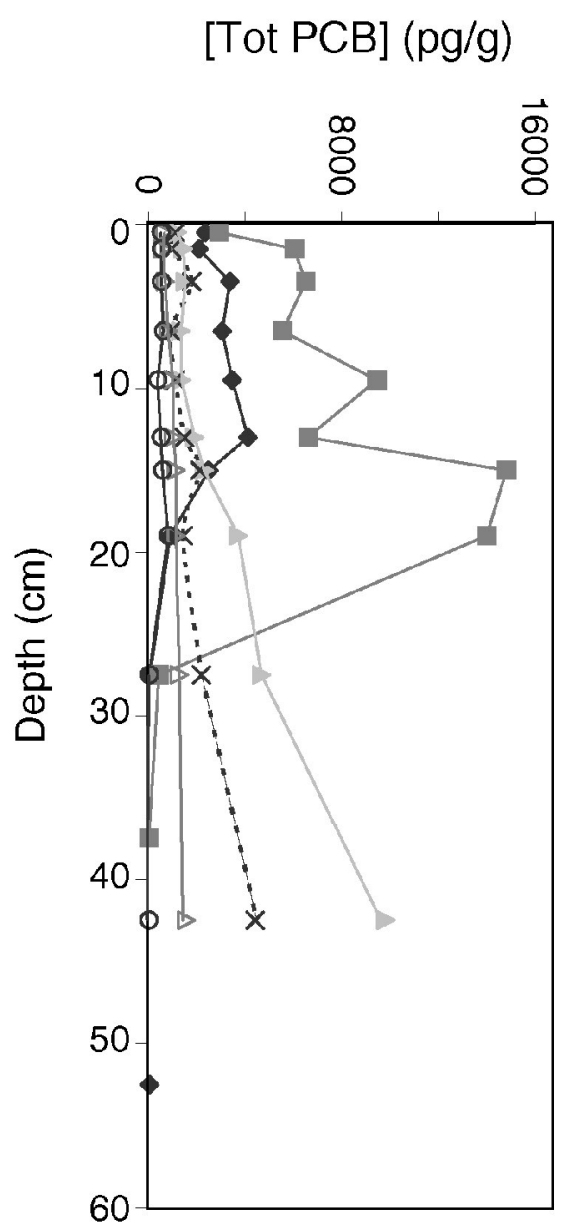

(a)
[Tot PBDE] (pg/g)

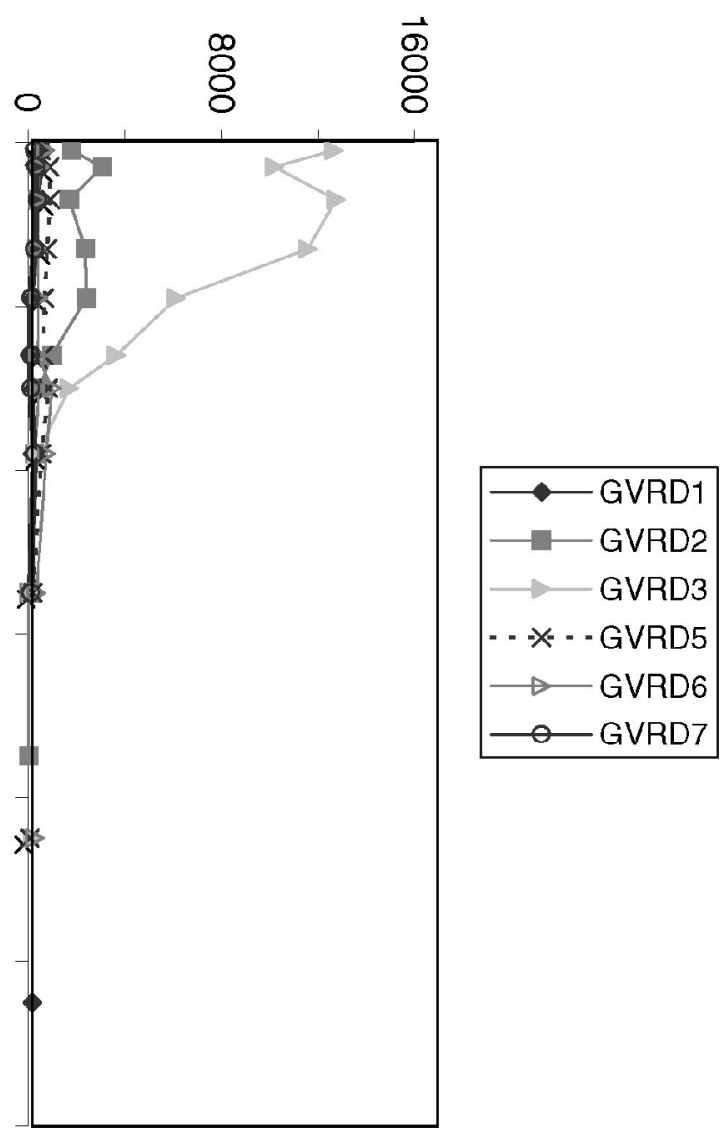

(b) 
Figure

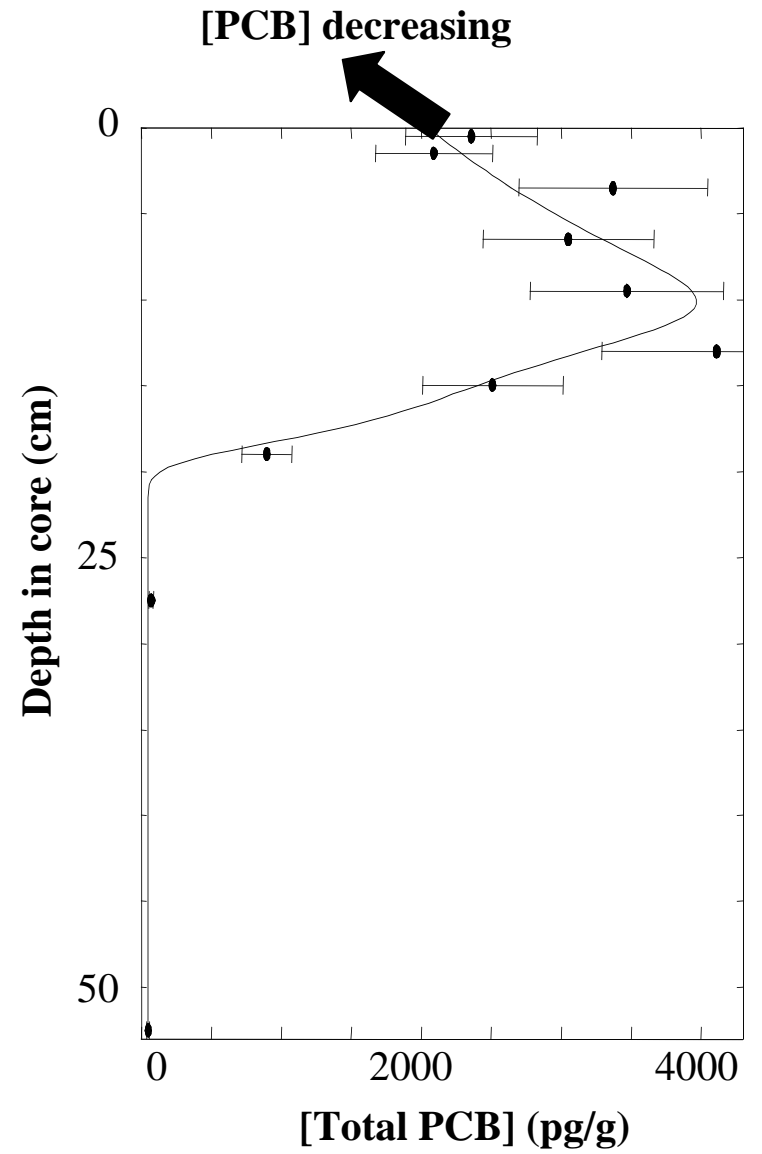

(a)
[PBDE] increasing

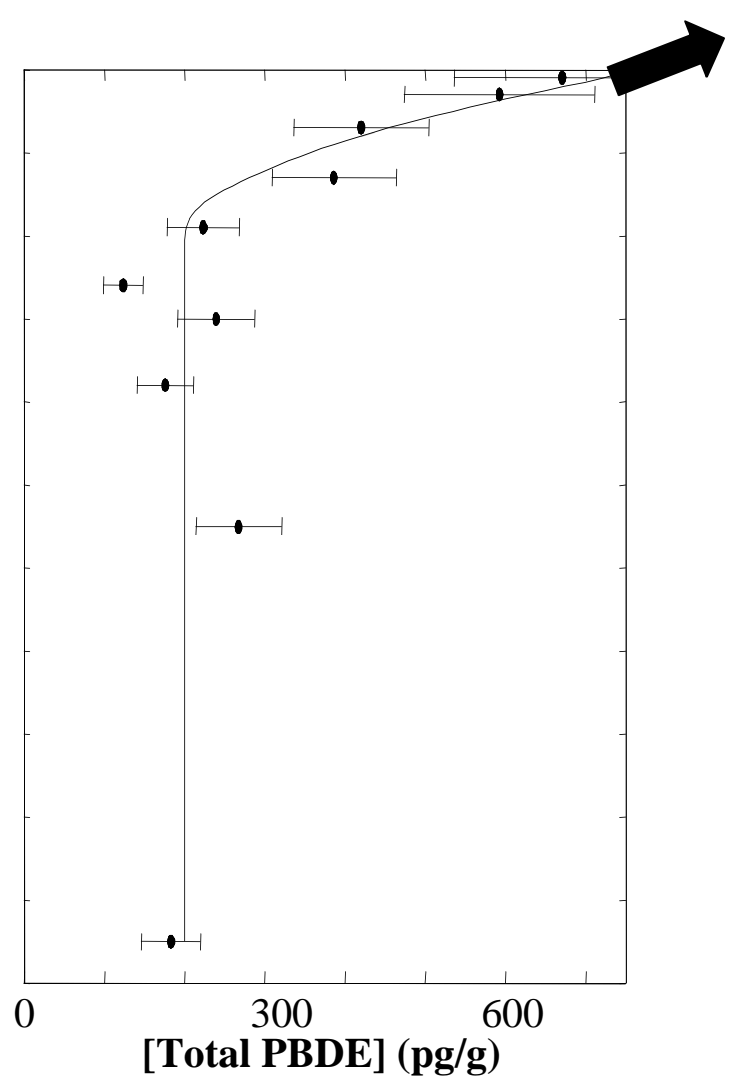

(b) 
Figure 6

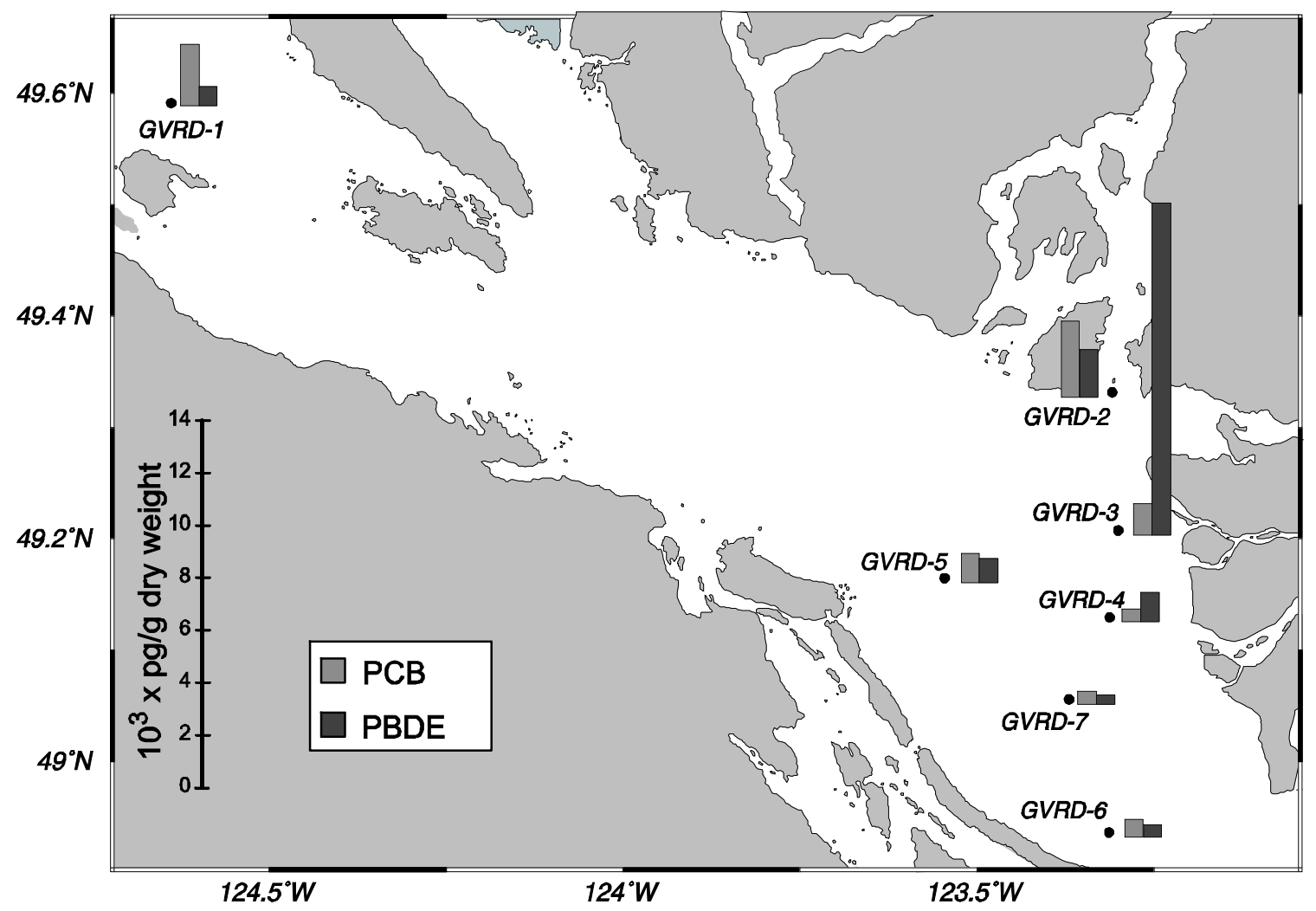

(a) Surface concentration

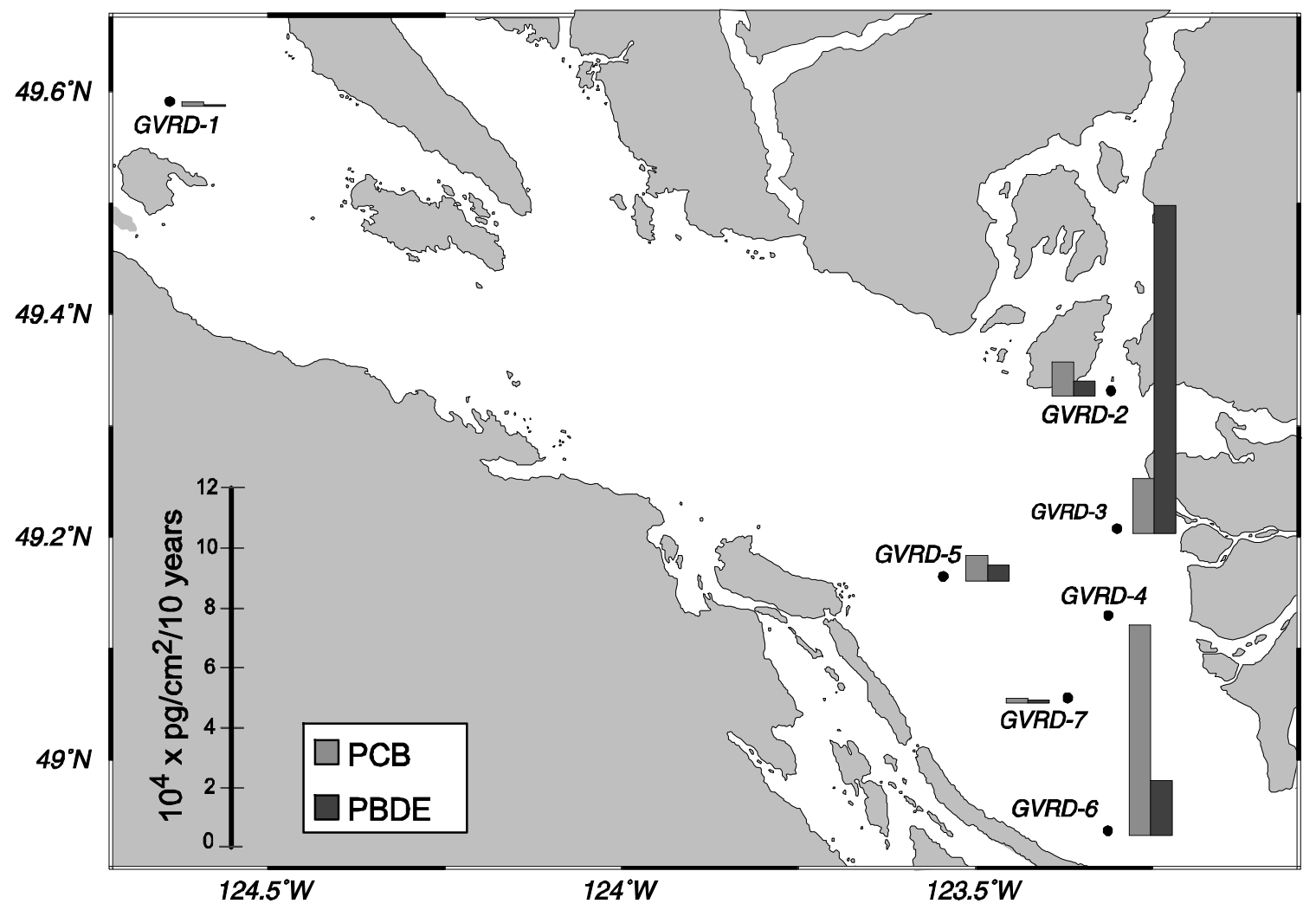

(a) 10-year inventory 
Figure

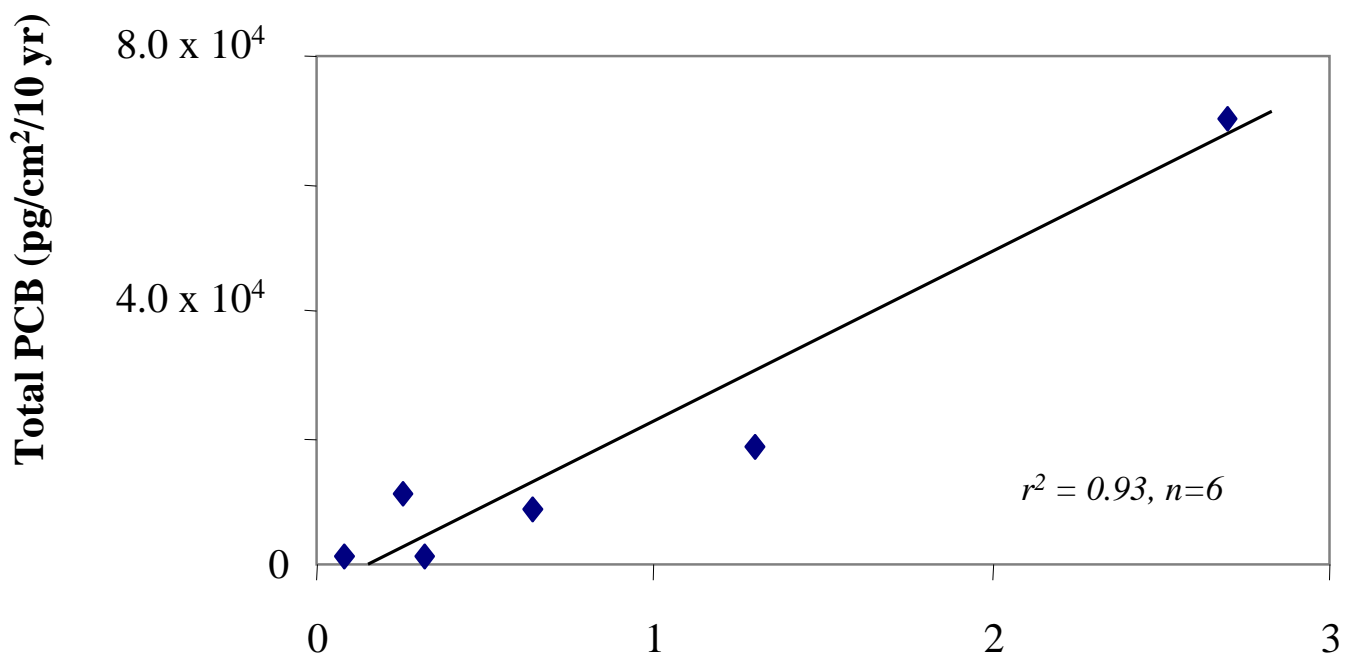

(a)

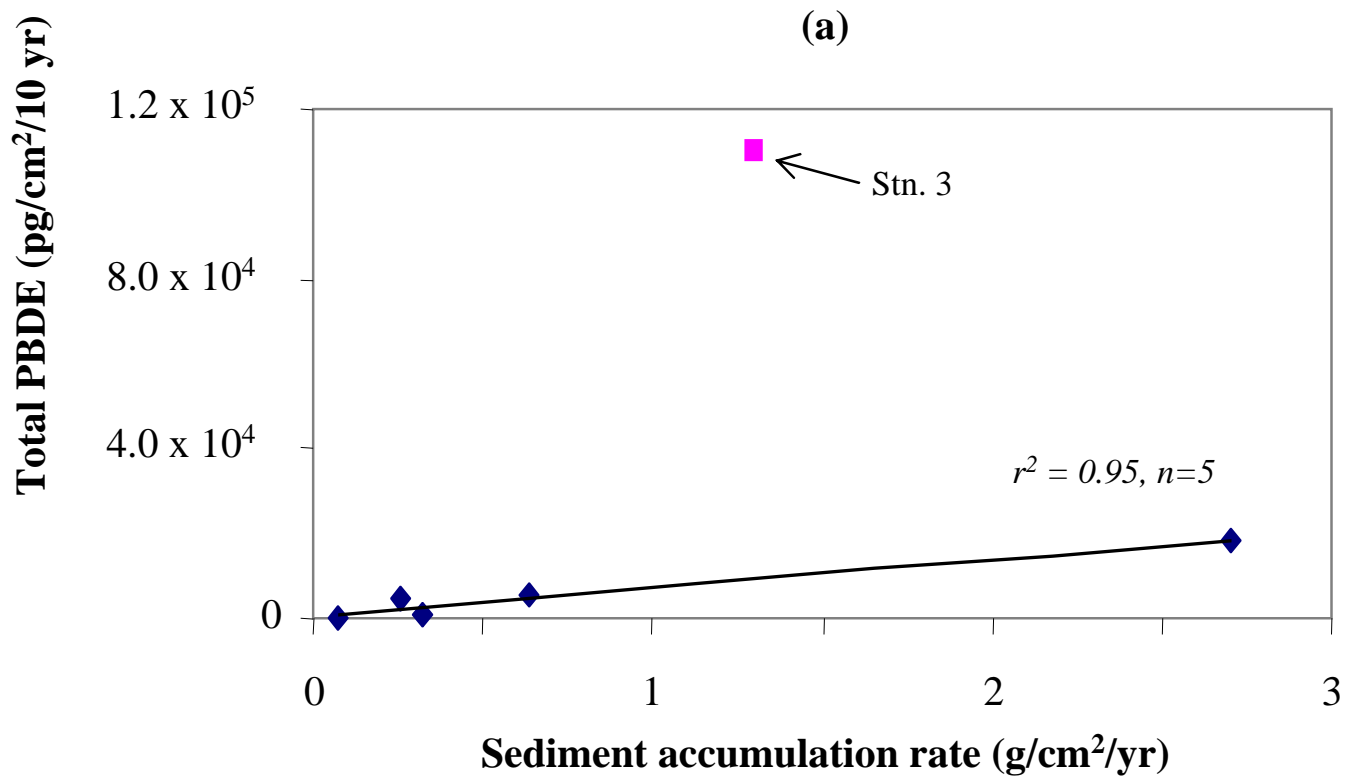

(b) 
Figure

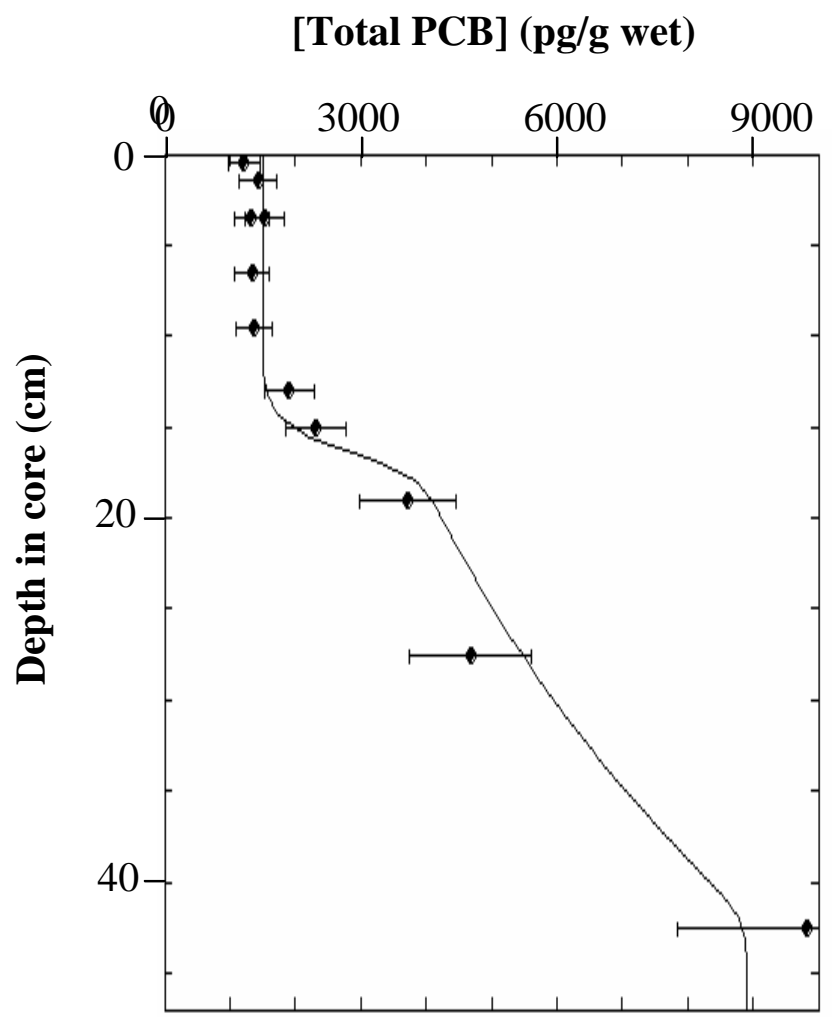


Figure

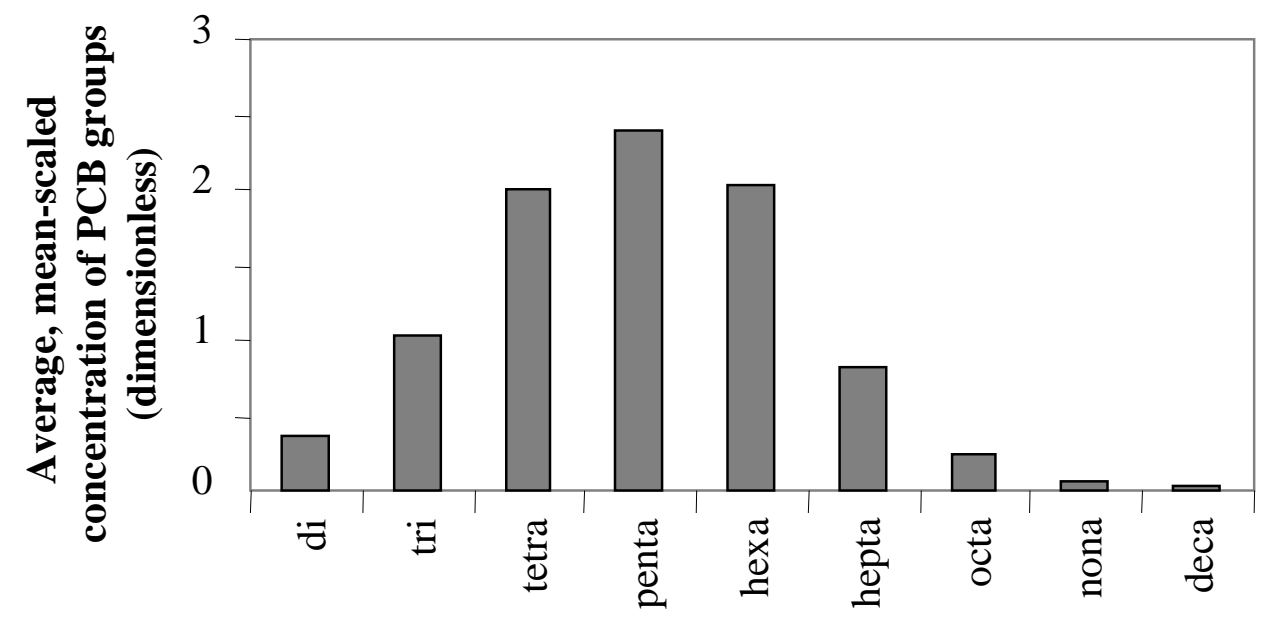

Degree of chlorination

(a)

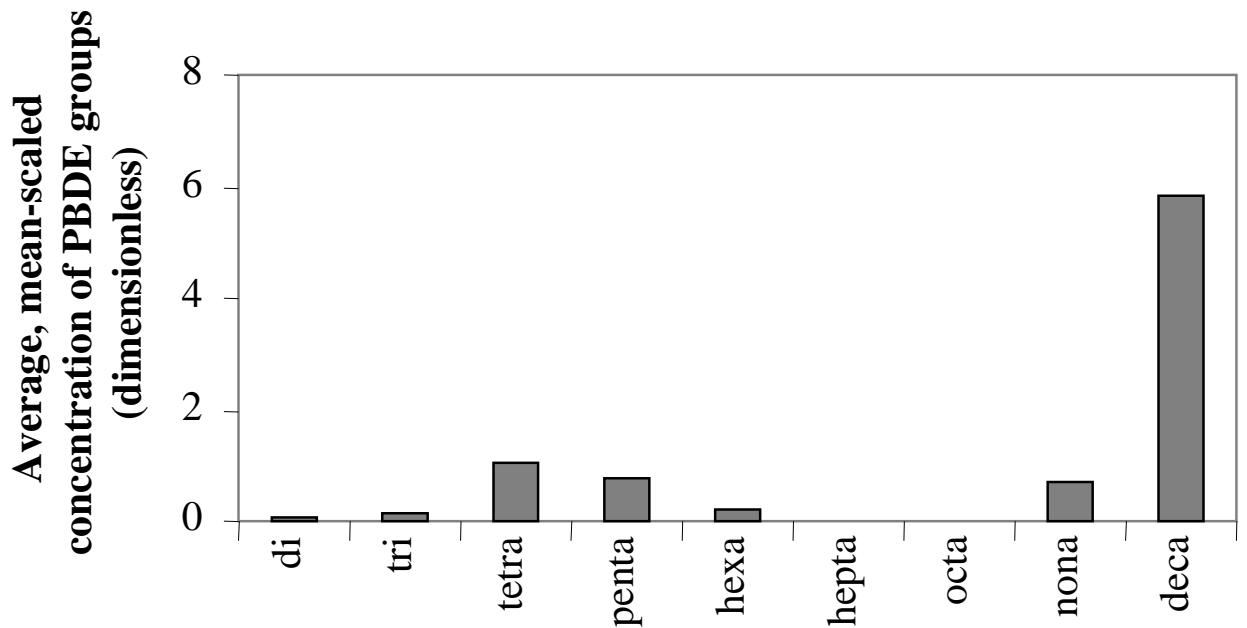

Degree of bromination

(b) 
Figure

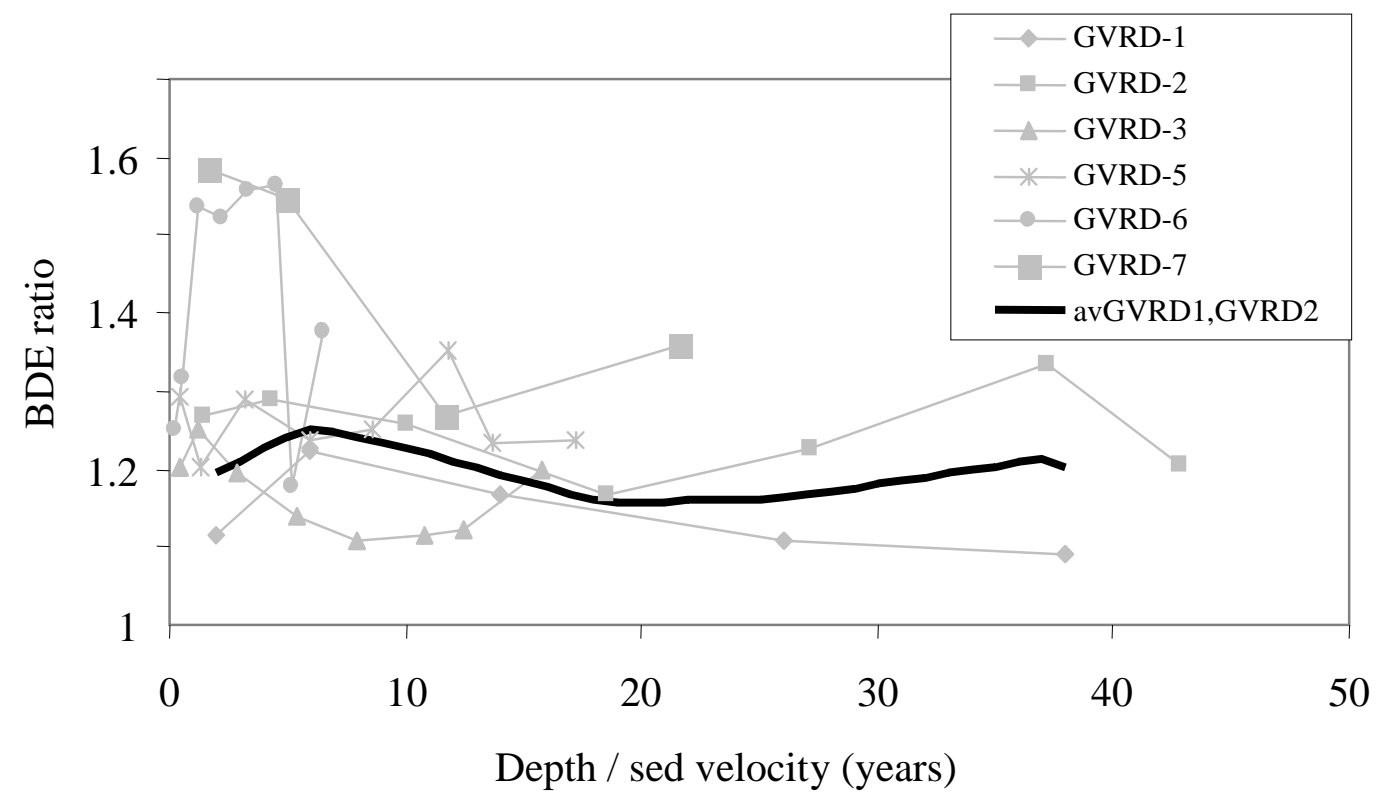

(a)

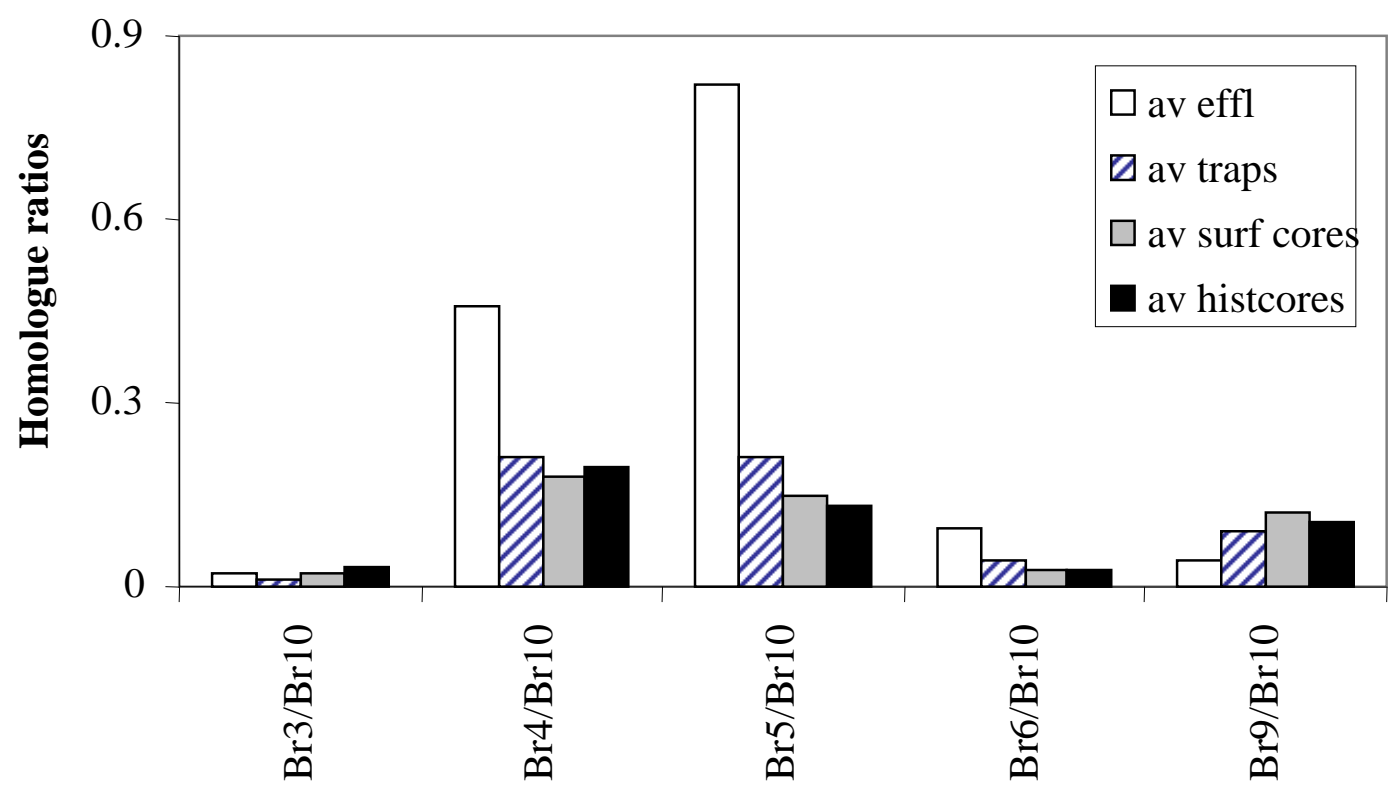

(b) 